\title{
Fluid and electrolyte imbalance related to intracranial abnormality
}

\author{
Frida Soesanti, Bambang Tridjaja, Jose RL Batubara, Aman Pulungan \\ From 7th APPES Biennial Scientific Meeting \\ Nusa Dua, Bali. 14-17 November 2012
}

\section{Background}

Maintenance of the tonicity of extracellular fluids is crucial for proper cell function. In children and adults, normal blood tonicity is maintained by a coordinated interaction among the thirst, vasopressin, and renal systems. Dysfunction in any of these systems can result in abnormal regulation of blood osmolality, which if not properly recognized and treated, may cause life-threatening dysfunction in neuronal and other cellular activities. The aim of this study is to increased awareness on the possibility of fluid and electrolyte imbalance in patients with intracranial abnormality.

\section{Case series}

There were five cases consulted to endocrinology division due to polyuriaduring February-June 2012. All of them had intracranial abnormality; Langerhans cell hystiocytosis $(\mathrm{LCH})$,cerebellimeduloblastoma, retinoblastoma with intracranial metastases, pituitary adenoma post extirpation, and intracranial abscess. During admission these patients develop polyuria, ranging from 6 to $16.6 \mathrm{~mL} / \mathrm{kg} /$ $\mathrm{hr}$. Etiology of polyuria were central diabetes insipidus in three patients (LCH, Meduloblastoma, pituitary adenoma patients), and CSW in two patients, the rate of urine were significantly higher in CDI than CSW cases. In CDI, the urine gravity was $<1.005$, the serum sodium was 138 $142 \mathrm{mEq} / \mathrm{L}$ with urine sodium of $8-36 \mathrm{mEq} / \mathrm{L}$, and the serum osmolality significantly higher than urine osmolality. None of our patient needed water deprivation test to confirm the diagnosis. Those with CDI were treated with DDAVP nasal spray. None of our patient had water intoxication due to DDAVP; instead the dose should be increased to $3 \times 20 \mathrm{mcg}$ in one patient. In the CSW patients, serum sodium level was quite low, reached $110 \mathrm{mEq} / \mathrm{L}$, manifest as seizure, and unresponsive to rapid sodium corrections. In these patients, the urine gravity was normal and urine sodium excretion was $>140 \mathrm{mEq} / \mathrm{L}$. None of these patients had specific signs of CSW. We increased sodium intake up to 10 $\mathrm{mEq} / \mathrm{kg} /$ day and maintained the fluid balance to prevent dehydration. One patient received fludrocortisone for one week. Four of 5 patients outcomes were good, but one patient died due to multiorgan failure associated with main disease.

\section{Conclusion}

Polyuria and electrolyte imbalance are not rarely occur during the course of other diseases, especially those with underlying intracranial pathology. Early identification and treatment of these condition will reduce morbidity and mortality associated with fluid and electrolyte imbalance and increase overall treatment outcome.

Published: 3 October 2013

doi:10.1186/1687-9856-2013-S1-P201

Cite this article as: Soesanti et al:: Fluid and electrolyte imbalance related to intracranial abnormality. International Journal of Pediatric Endocrinology 2013 2013(Suppl 1):P201.
Pediatric Endocrinology Division, Faculty of Medicine, Universitas Indonesia, Ciptomangunkusumo Hospital, Jakarta, Indonesia
() 2013 Soesanti et al; licensee BioMed Central Ltd. This is an Open Access article distributed under the terms of the Creative Commons Attribution License (http://creativecommons.org/licenses/by/2.0), which permits unrestricted use, distribution, and reproduction in any medium, provided the original work is properly cited. 